\title{
Glucostatic control of intake and obesity
}

\author{
BY ARNE ASTRUP AND ANNE RABEN \\ Research Department of Human Nutrition and Centre of Food Research, The Royal Veterinary \\ and Agricultural University, Rolighedsvej 30, DK-1958 Frederiksberg C, Copenhagen, Denmark
}

\section{Contrôle glucostatique de l'apport alimentaire et obésité}

\begin{abstract}
RÉSUMÉ
L'effet des trois macronutriments (glucides, lipides et protides) sur la régulation de l'appétit est complexe et implique plusieurs mécanismes différents dont certains sont non-spécifiques (la densité énergétique par exemple), alors que d'autres mécanismes sont réservés à des macronutriments spécifiques (glucostatique et lipostatique par exemple). Le pouvoir de satiété de chaque nutriment, en les comparant joule pour joule, est inversement proportionnel à sa capacité de stockage, les protéines étant ceux qui ont les plus grand effet de satiété, suivis par les glucides et les graisses. Un effet pré-absorptif de la densité énergétique semble être un déterminant puissant de la prise d'aliment, en particulier dans la médiation d'hyperphagie causée par des régimes élevés en graisses, et faibles en glucides chez des sujets normaux. De nombreuses preuves montrent qu'il existe un effet métabolique post-absorptif spécifique du glucose sur la régulation de l'appétit; pourtant, la nature de ce phénomène s'explique mal et pourrait impliquer des mécanismes glucostatiques, glycogénostatiques et métaboliques.

Des ajustements de la prise d'énergie peuvent se produire en réponse à des modifications induites métaboliquement dans l'utilisation du glucose, par exemple au cours de l'exercice physique intense, mais on ne sait pas bien dans quelle mesure les mécanismes glucostatiques interviennent dans les modifications dans la prise d'énergie qui se produisent quand le rapport graisses:glucides est modifié. Il est possible que la densité énergétique soit d'une importance promordiale dans la régulation à court terme du poids du corps chez les mangeurs non restreints qui n'ont pas de prédisposition génétique à l'obésité, mais à long terme il semble que leur poids corporel soit assez résistant aux modifications dans le rapport graisses:glucides de leur alimentation. Au contraire, les mangeurs restreints et les individus qui ont une prédisposition génétique à l'obésité sont extrêmement sensibles à une composition élevée en graisses et faible en glucides dans leur alimentation, qui favorise un équilibre positif des graisses, essentiellement en augmentant l'apport d'énergie. Dans ce groupe vulnérable d'individus, l'augmentation des graisses dans l'alimentation peut dépasser leur capacité d'autorégulation à élever l'oxydation des graisses immédiatement, c'est-à-dire causer la séparation des nutriments des graisses pour favoriser le stockage par rapport à l'oxydation. Il se peut que le bilan négatif des glucides qui accompagne ce phénomène soit responsable de l'augmentation de la prise d'énergie, agissant par des mécanismes glucostatiques. L'augmentation des dépôts de graisses peut, à son tour, être responsable des mécanismes d'adaptation tels que l'augmentation des niveaux de substrats lipidiques et la résistance à l'insuline, qui augmente en même temps l'oxydation des graisses jusqu'au niveau du contenu en graisses de l'alimentation. Il est possible que la première étape de ce
\end{abstract}


processus auto-limitant soit déclenché par une préférence génétiquement déterminée pour les aliments riches en graisses, et qui peut s'exprimer dans une société qui a des aliments en abondance, facilement disponibles, et appétissants du fait de leur contenu riche en graisse.

\section{GLUCOSTATIC MECHANISMS IN CONTROL OF FOOD INTAKE}

Several tissues need specific fuels such as glucose, particularly during conditions requiring high energy. Due to the limited size of the glycogen stores (compared with fat and protein stores), it seems likely that some glucostatic mechanisms exist and operate in concert with other lipostatic and gastrointestinal feedback mechanisms (Mayer, 1955). When carbohydrate intake is restricted, the maintenance of a sufficient glucose supply to certain tissues may be ensured by sparing glucose, by utilization of fat as fuel in tissues where possible, or by increased glucose production from amino acids and glycerol, i.e. gluconeogenesis. If these mechanisms are insufficient to maintain an appropriate glucose supply, signalling to the central nervous system occurs, resulting in hunger sensations which would usually lead to food intake. Conversely, a re-establishment of glucose availability and replenishment of glycogen stores may bring about signals from the periphery to inhibit food intake. Although adjustments of energy intake occur in response to metabolically-driven changes in glucose utilization, for example during high-intensity exercise, there is no concordant view as to whether glucostatic mechanisms are involved in the changes in total energy intake that occur when the dietary fat:carbohydrate is altered. A prerequisite for the assumption that specific control mechanisms regulate the intake of carbohydrate is that variations and changes in dietary carbohydrate intake caused by external environmental factors are met by regulatory adjustments which attempt to correct the error. Corrective behaviour may be mediated either by craving and/or increased preference for carbohydrate-rich foods, or by increased consumption of the usual diet until carbohydrate needs are satisfied. The former mechanism has been described in humans (King \& Blundell, 1995) but it is less powerful than in animals, probably due to the ample supply of highly palatable foods available to humans. If the latter mechanism is operating one might expect total energy intake to be inversely related to the carbohydrate content of the diet, i.e. food is consumed until a certain absolute amount of carbohydrate has been ingested. However, this view is too simplistic because carbohydrate needs are also modulated by appropriate adjustments of fat and carbohydrate oxidation rates, i.e. oxidative autoregulation. Nevertheless, changes in energy balance and body fat will occur since autoregulation cannot completely offset changes in dietary carbohydrate content, in which case relationships between dietary carbohydrate content and body fatness should exist. A number of different study types and designs can be applied to look for such relationships, and the observational epidemiological evidence derived from cross-sectional, casecontrol and longitudinal studies are briefly reviewed.

\section{DIETARY CARBOHYDRATE AND OBESITY}

\section{Observational studies}

Numerous population studies have assessed the relationship between the carbohydrate content of habitual diets and current body fatness (cross-sectional surveys) or subsequent 
weight change (longitudinal studies). Recent reviews focused on the the importance of either dietary fat (Lissner \& Heitmann, 1995) or carbohydrate (Astrup \& Raben, 1995; Hill \& Prentice, 1995). Dissociation of the effects of these two macronutrients is difficult as their relative proportions of dietary energy are so closely inversely related. Generally the cross-sectional studies have been able to show quite robust inverse relationships between dietary carbohydrate content and body fatness. The proportion of the total variation in body fat size explained by differences in dietary carbohydrate is usually low, e.g. $16 \%$ in one study (Dreon et al. 1988). However, one should bear in mind that the margin of error inherent in the techniques for the collection of information about habitual dietary intake is large; this may be particularly so among obese individuals. The imprecision of self-recorded body weight and height are further sources of errors tending to dilute the true relationships. In particular, one may suspect the pronounced under-reporting of energy intake of obese subjects to be greatest in the case of fatty foods. Consequently, the reported values should be considered as minimum estimates. Moreover, case-control studies have consistently shown that obese subjects habitually consume a diet with a higher fat content and lower carbohydrate content than non-obese controls (Astrup \& Raben, 1995), and these observations have been confirmed by objective, indirect measurements of $24 \mathrm{~h}$ substrate oxidations (Astrup et al. 1994a).

Longitudinal studies relating dietary carbohydrate content to subsequent weight change look more ambiguous (Astrup \& Raben, 1995). The reason for this may be the unrepresentativeness of a diet history or a $7 \mathrm{~d}$ food record for the habitual dietary intake over a period of years. Moreover, correlations may be diluted by inclusion of subjects not susceptible to weight gain when consuming a low-carbohydrate diet. This hypothesis is supported by a recent study where a cohort of 361 adult women was followed for 6 years after ascertaining baseline dietary information. Only in women already overweight at baseline and having at least one obese parent was the consumption of a high-fat diet (>40\% fat energy) associated with a significant 6-year weight gain, while no relationship was found among obese women with lean parents or lean women independent of parental body weight (Heitmann et al. 1995). In the group susceptible to the high-fat (or low-carbohydrate) diet the risk of gaining $>3$ BMI units in 6 years was nine-fold higher than that in the other groups.

So, from this brief review of the observational studies, it can be concluded that individuals with a genetic predisposition are at high risk for weight gain and obesity when consuming high-fat low-carbohydrate diets. Moreover, high-fat low-carbohydrate diets are also involved in the maintenance of the obese state, as suggested by the crosssectional studies and case-control studies, and the evidence is further strengthened by another line of evidence stemming from the intervention studies.

\section{Intervention studies}

In animal studies a high-carbohydrate low-fat diet ( $<30 \%$ fat energy) protects against overweight and obesity, at least in models where obesity is not caused by hypothalamic lesions or genetic syndromes. In rodents there is quite convincing evidence of the effect of dietary carbohydrate on both sides of the energy balance equation. A high-fat low-carbohydrate diet is typically associated with hyperphagia (Sclafani, 1980), but even when fed isoenergetically it is possible to demonstrate an increase in fatness of rats in a classical dose-response to increases in dietary fat content (Boozer et al. 1995). This must 
be due to increased energy expenditure on the low-carbohydrate diet as compared with the high-fat diet, probably induced by the carbohydrate content stimulating sympathetic nervous system activity. Most studies in humans have failed to show increased $24 \mathrm{~h}$ energy expenditure with high-carbohydrate diets (Abbott et al. 1990; Hill et al. 1991), but subsequent studies have shown that high-carbohydrate diets produce a small, but significant, increase in $24 \mathrm{~h}$ energy expenditure, at least in individuals with a predisposition to obesity (Astrup \& Raben, 1992; Astrup et al. 1994a). Nevertheless, it is quite obvious that the ability of high-carbohydrate diets to promote a negative fat balance is exerted predominantly through a reduction in energy intake. Several intervention studies have demonstrated that a low-fat high-carbohydrate diet consumed ad lib. over weeks or months reduces energy intake and promotes weight loss proportionally with initial body fatness (Raben \& Astrup, 1996).

Taken together, the observational data support an important role for lowcarbohydrate diets in promoting weight gain in genetically-predisposed individuals, and in maintaining stable fat stores in obese subjects. The numerous dietary intervention studies support a causal role for low-carbohydrate diets in the development of obesity because obesity can be partially reversed and relapse prevented by ad lib. consumption of high-carbohydrate low-fat diets (Toubro \& Astrup, 1995), at least of course if the patients stick to the diet (Lyon et al. 1995). These observations are in agreement with the existence of glucostatic components in the regulation of food intake, but they do not prove that they are responsible for the relationship between dietary carbohydrate and body fatness, which might also be due to alternative mechanisms.

\section{Carbohydrate and appetite control}

The substantial literature demonstrating how the fat:carbohydrate value of the diet influences energy intake is supported by appetite control studies, which have demonstrated a greater satiating power of carbohydrates $v$. fat, kJ-for-kJ (Blundell et al. 1993). It has been proposed that the less effective suppression of appetite caused by fat than by carbohydrate may be a result of the higher energy density of fat than carbohydrate. It is difficult to separate the impact of energy density from an unrelated macronutrientspecific property such as the glucostatic effect, because foods rich in fat have a high energy density and vice versa. The combined data of two studies sponsored by the Unilever Research Laboratorium in Vlaardingen (De Graaf et al. 1992; Hulshof et al. 1993) produced dose-response curves for the satiating action of proteins, carbohydrates and fat (Fig. 1). These curves are compatible with the hypothesis that the satiating powers are related to the storage capacities of each macronutrient.

While the energy density of meals is thought to promote post-ingestive satiety, perhaps mediated through afferent vagal fibres and gastrointestinal hormones, post-absorptive effects on appetite have been ascribed mainly to macronutrient-related effects, for example fat oxidation (lipoprivic feeding) and glucose utilization (glucoprivic feeding; Ritter \& Taylor, 1990). There are several possibilities for means whereby a glucostatic control mechanism may influence appetite control, for example via plasma glucose and insulin acting on glucose sensors, or events and/or signals serving to cause replenishment of glycogen stores. In a classical study Mayer (1955) found excellent correlations between overall glucose utilization, measured by arterio-venous $(\mathrm{A}-\mathrm{V})$ differences in glucose concentration, and the subjective expression of hunger. A large $\mathrm{A}-\mathrm{V}$ glucose 


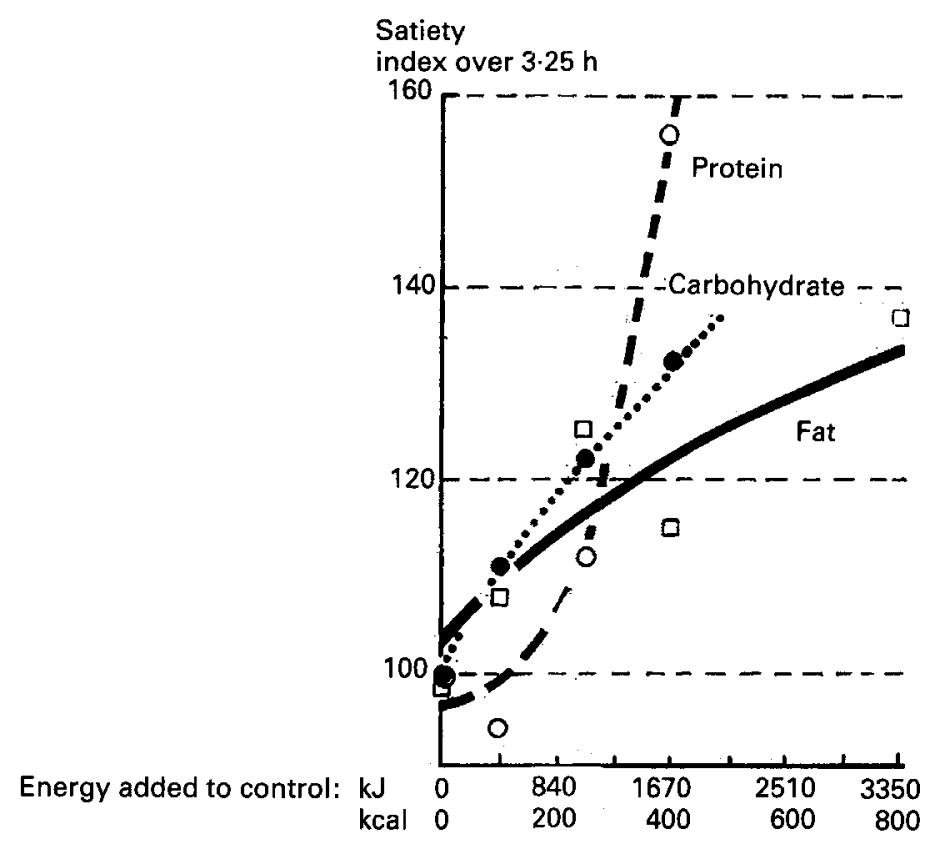

Fig. 1. Satiety index over $3 \cdot 25 \mathrm{~h}$ measured in healthy, normal weight males and females (19-26 years), after ingestion of approximately $550 \mathrm{ml}$ liquid preloads varying in energy (from $420 \mathrm{~kJ}(100 \mathrm{kcal})$ to about $3350 \mathrm{~kJ}$ $(800 \mathrm{kcal}))$ and fat, protein and carbohydrate content. ( $\square)$, Fat preloads; $(\bigcirc)$, protein preloads; $(\bigcirc)$, carbohydrate preloads. The figure shows that protein gives the highest satiety (in $3.25 \mathrm{~h}$ ) followed by carbohydrates. The lowest satiety was recorded for fat: $3350 \mathrm{~kJ}(800 \mathrm{kcal})$ fat is needed to match an equivalent effect for $1670 \mathrm{~kJ}$ ( $400 \mathrm{kcal}$ ) carbohydrate or over $1255 \mathrm{~kJ}$ (300 kcal) protein. (Modified from De Graaf et al. 1992; Hulshof et al. 1993).

difference was found to coincide with satiety. Both centrally-located and hepatic sensors are involved in monitoring glucose concentration and are highly influenced by insulin action, and liver glycogen content is monitored indirectly and gives rise to afferent signals influencing food intake (Tordoff et al. 1989). However, it is difficult to assess how important carbohydrate-specific systems are in the regulation of human food intake. Stubbs and colleagues (Stubbs et al. 1993; Stubbs \& Prentice, 1993) have tried to distinguish between energy density and macronutrient-specific impact on appetite in normal weight subjects. They covertly manipulated the dietary fat content of isoenergetically-dense diets and observed the ad lib. food intake in non-obese males (Stubbs \& Prentice, 1993). They found that hyperphagia previously found on a high-fat lowcarbohydrate diet (Stubbs et al. 1993) was almost abolished when the energy density of the high-fat diet was reduced, while the isoenergetically-dense low-fat high-carbohydrate diet reduced energy intake by about $10 \%$, and caused a slight weight loss over $3 \mathrm{~d}$. Moreover, in a joint analysis of sixty-four test meals with different carbohydrate contents, slightly weaker positive correlations were found between the change in mean postprandial satiety and energy density $(r 0.89)$ than between the change in mean postprandial satiety and postprandial response of plasma glucose $(r 0.92)$, lactate ( $r$ 0.98), insulin ( $r$ 0.95) and noradrenaline ( $r$ 0.97; Raben et al. 1996). These findings suggest that postprandial satiety induced by carbohydrate is closely linked to some intracellular event determined by glucose uptake and insulin action. Taken together 
these studies suggest that high-fat diets have a weak satiating power due to their high energy density, but that a high-carbohydrate diet inhibits energy intake by a metabolic action which goes beyond its energy density.

\section{CARBOHYDRATE USE AND APPETITE CONTROL}

Can energy intake be enhanced or inhibited through a glucostatic mechanism influencing hunger and satiety, driven by the cellular demand for utilization of glucose? Glucose utilization is obligatory for several tissues but these may not play an important role quantitatively, due to the flexibility of other tissues and organs to use fat as fuel, i.e. compensatory adjustments made in oxidative autoregulation. At rest only a small proportion of the muscle fuel is made up of carbohydrates and this consists almost entirely of plasma glucose (Wahren et al. 1971). Plasma-derived non-esterified fatty acids (NEFA) are the dominant fuel in muscle at rest and have been estimated to correspond to $80 \%$ of resting muscle energy expenditure (Havel et al. 1967). A close relationship exists between the plasma NEFA concentration and the amount being oxidized (Hagenfeldt \& Wahren, 1971; Astrup et al. 1992), and it has been shown that plasma NEFA promotes its own oxidation (Bonadonna et al. 1990). At the start of exercise both fuels (NEFA and glucose) are utilized, but marked differences in substrate utilization during exercise exist depending on type, duration, intensity, frequency and training. Generally, the reliance on carbohydrates as energy source increases with the exercise intensity and with the carbohydrate content of the pre-exercise diet, and decreases with the fitness level of the individual. Tremblay et al. (1994) compared two different exercise programmes featuring either a preferential fat or carbohydrate use, and found a larger reduction in body fat and increase in muscle activities of $\beta$-oxidative enzymes after the 'fat-burning' programme, despite its lower total energy cost. This study suggests that energy expenditure which is preferentially fuelled by fat oxidation and spares the use of glucose, is followed by hunger and subsequent compensatory food intake to a lesser extent than energy expenditure fuelled by glucose. King \& Blundell (1995) have also reported a relationship between $\mathrm{RQ}$ during exercise and subsequent food selection (in terms of food quotient; $\mathrm{CO}_{2}$ produced: $\mathrm{O}_{2}$ consumed during biological oxidation of a representative sample of the diet, FQ), which also suggests that use of carbohydrate not only stimulates food intake but may also activate macronutrient-specific food preferences.

\section{GLUCOSTATIC MECHANISMS IN PRE-OBESE, OBESE AND POST-OBESE}

It is quite obvious that the specific demand for abundant supplies of either glucose or fat during various kinds of exercise may bring about $R Q$ values which differ from the $F Q$ of the diet because the limits for oxidative autoregulation operating in non-exercising tissues are exceeded. However, during dietary manipulations of glycogen stores normal subjects seem to manage to cope with marked perturbations by adjustments of $R Q$, so that replenishment of glycogen stores after low-carbohydrate diets is not achieved by increased energy intake, but rather by a decrease in glucose oxidation (Shetty et al. 1994). While this may be true for never-obese subjects, the autoregulatory apparatus may be insufficient in subjects genetically predisposed to obesity, and this failure may be responsible for their progressive weight gain when challenged with an increase in dietary fat:carbohydrate. 


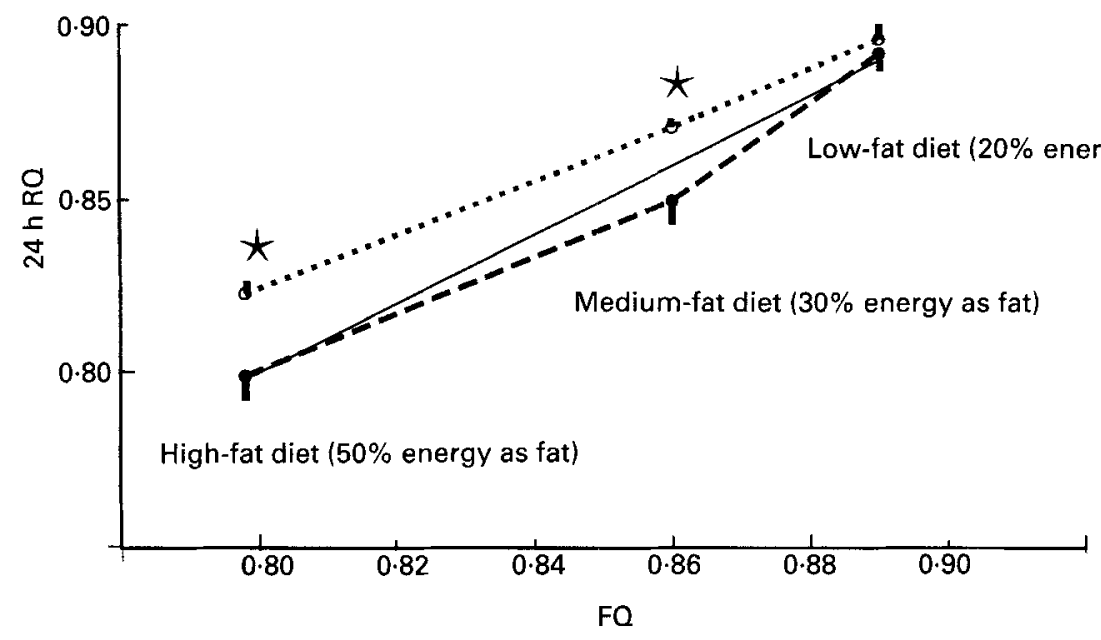

Fig. 2. Responsiveness of oxidative autoregulation in formerly obese women with the genetic predisposition to

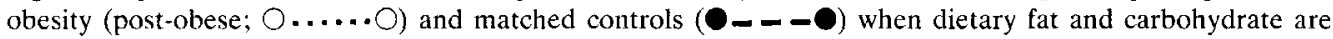
manipulated (recalculated from Astrup et al. 1994). The diet composition is expressed as the food quotient (FQ), which is $\mathrm{CO}_{2}$ produced: $\mathrm{O}_{2}$ consumed during the biological oxidation of a representative sample of the diet, while the actual combusted macronutrient mix is expressed as $24 \mathrm{~h} \mathrm{RQ}$ as measured in an indirect calorimeter after $4 \mathrm{~d}$ isoenergetic consumption of each diet. Complete adjustment of the oxidation pattern to equal the consumed macronutrients is achieved when $\mathrm{FQ}=\mathrm{RQ}$, as indicated by the line of identity (predicted). The controls did not deviate from the predicted line, i.e. they autoregulated completely, while the post-obese group did not manage to suppress their glucose oxidation and increase fat oxidation appropriately when the dietary fat content progressively increased at the expense of the carbohydrate content. The resulting deficit in $24 \mathrm{~h}$ carbohydrate balance in the post-obese subjects on the diet with $50 \%$ energy as fat is suggested to stimulate hunger and subsequent energy intake. Significantly different from matched controls: ${ }^{*} P<0 \cdot 05$.

\section{Metabolic susceptibility to low-carbohydrate diets}

Overweight individuals with a genetic predisposition to obesity gain weight when challenged with a diet composition characterized by low-carbohydrate high-fat contents (Heitmann et al. 1995). Covert manipulation of isoenergetic amounts of fat and carbohydrate in preload meals has shown in obese and non-obese restrained eaters that high-fat preloads inhibit subsequent intake to a lesser extent than high-carbohydrate preloads (Rolls et al. 1994). By contrast, normal subjects compensated accurately for energy differences independent of macronutrient composition in the preloads. There are several lines of evidence of a metabolic background for the abnormal response to a high-fat low-carbohydrate diet in susceptible individuals. Restrained eaters failed to increase $24 \mathrm{~h}$ fat oxidation to the same extent as non-restrained eaters when challenged by a high-fat low-carbohydrate diet (Verboeket-van de Venne et al. 1994). The accompanying deficit in carbohydrate balance is suggested to stimulate energy intake through glucostatic mechanisms. In Pima Indians a high $24 \mathrm{~h}$ glucose:fat oxidation (high $\mathrm{RQ}$ ), measured in weight-stable subjects on a standardized diet staying on a metabolic ward, was found to be associated with an increased risk for subsequent weight gain (Zurlo et al. 1990). Seidell et al. (1992) found that non-obese Caucasian men with a high fasting RQ $(>0.85)$ were found to have a 2.4 -fold higher risk of gaining more than $5 \mathrm{~kg}$ than those with a low fasting RQ $(<0 \cdot 76)$. However, this study did not strictly control antecedent diet and energy balance, which are crucial for the interpretation (Astrup \& 
Flatt, 1996). Once the obese condition has developed, fat oxidation does not increase after high-fat diets to the same extent as that in normal-weight control subjects (Thomas et al. 1992), but one should recognize that fat oxidation, whether expressed as $\mathrm{g} / \mathrm{d}$ or as $\%$ of total energy expenditure, is already higher in obese subjects than in non-obese subjects (Astrup et al. 1994b). Due to this confounding effect of the obese state, formerly obese subjects with the genetic predisposition to obesity (so-called post-obese) may be a more suitable experimental model. A number of studies have disclosed that in post-obese subjects, $24 \mathrm{~h}$ RQ equals $\mathrm{FQ}$ and $\mathrm{RQ}$ of never-obese subjects when consuming a low-fat high-carbohydrate diet, i.e. a high-FQ diet (Fig. 2). When the dietary fat content is increased at the expense of carbohydrate (FQ is decreased) the controls make complete autoregulatory adjustments so that $\mathrm{RQ}=\mathrm{FQ}$. By contrast, the post-obese subjects deviate progressively from the expected $24 \mathrm{~h} \mathrm{RQ}$, which results in positive $24 \mathrm{~h}$ fat balances and negative carbohydrate balances (Astrup et al. 1994a). In a subsequent study by Buemann et al. (1994) the change from a low-fat high-carbohydrate to a high-fat low-carbohydrate diet was made under strictly-controlled energy-balance conditions ove $5 \mathrm{~d}$ in a calorimeter. In this study the $24 \mathrm{~h}$ fat oxidation profile was completely normal in the post-obese subjects while on the low-fat diet, but on the following four consecutive days, when they consumed the high-fat diet, the postprandial fat oxidation was consistently suppressed in the post-obese group. In a third study, the postprandial metabolic response was examined in more detail using the ventilated canopy system (Raben et al. 1994). It was shown that post-obese women exhibited higher glucose oxidation and decreased fat oxidation than a closely-matched control group after a high-fat meal, and a number of endocrine alterations in the post-obese subjects are suggestive of a complex set of mechanisms being responsible (Raben et al. 1994).
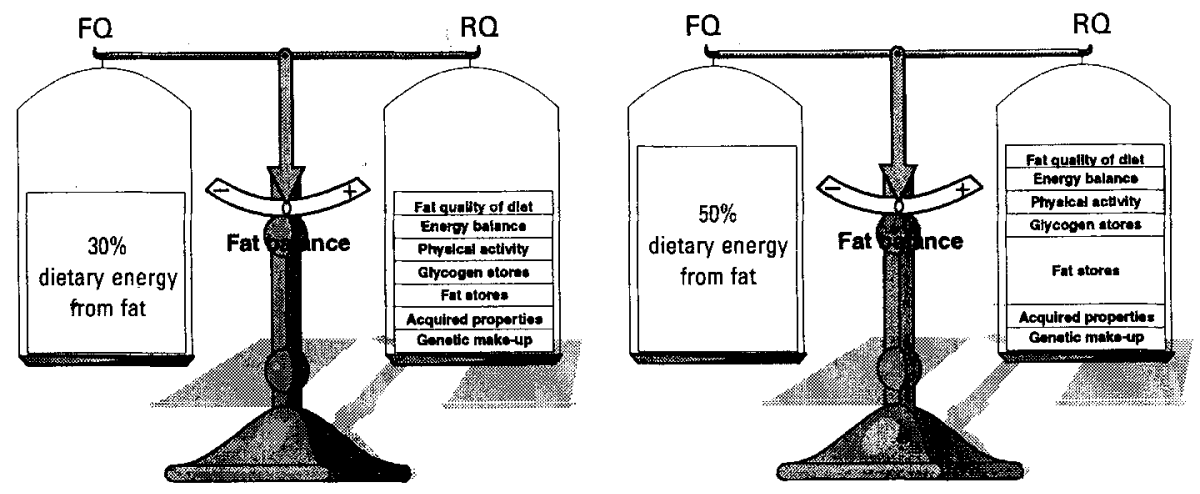

Fig. 3. Weight stability can only be achieved when fat balance equals zero, which requires that overall the fuel mixture oxidized (RQ) equals the macronutrient mixture of the diet (food quotient (FQ); $\mathrm{CO}_{2}$ produced: $\mathrm{O}_{2}$ consumed during biological oxidation of a representative sample of the diet). In most individuals stable body fat stores can be achieved on the ad lib. consumption of a diet providing $30 \%$ energy from fat. When a high-fat diet is consumed over prolonged periods of time, subjects with the genetic predisposition to obesity do not manage to increase fat oxidation sufficiently, i.e. to decrease $R Q$ to equal $F Q$, and macronutrient balance occurs. The fat stores are enlarged until fat oxidation is increased to decrease RQ to equal FQ. At what size the enlargement of fat stores is sufficient may depend on genetic make-up, early environmental influences, physical fitness, glycogen stores, dietary fat quality, insulin resistance and other unknown factors. 


\section{CONCLUSION}

In conclusion, individuals with a genetic predisposition to obesity are vulnerable to a high-fat low-carbohydrate diet because an increased proportion of fat in the diet may exceed the immediate autoregulatory capacity to raise fat oxidation, i.e. cause the nutrient partitioning of fat to favour storage over oxidation. The accompanying negative carbohydrate balance is likely to be responsible for the subsequent increased energy intake, working through glucostatic mechanisms. The increased fat deposition may, in turn, be responsible for adaptive mechanisms, such as increased plasma levels of fat substrates (NEFA) promoting their own oxidation, and also insulin resistance, these together increasing fat oxidation until RQ has increased to equal FQ (Fig. 3). This concept is supported by several lines of evidence (for review, see Astrup \& Flatt, 1996). This self-limiting process may be triggered by a genetically-determined preference for high-fat foods which is allowed to be expressed in a society with abundantly available palatable high-fat foods.

The authors thank Dr Jan Weststrate of Unilever Research Laboratorium in Vlaardingen, the Netherlands, for kind permission to reproduce Fig. 1.

\section{REFERENCES}

Abbott, W. G. H., Howard, B. V., Ruotolo, G. \& Ravussin, E. (1990). Energy expenditure in humans: effects of dietary fat and carbohydrate. American Journal of Physiology 258, E347-E351.

Astrup, A., Buemann, B., Christensen, N. J., Madsen, J., Gluud, C., Bennet, P. \& Svenstrup, B. (1992). The contribution of body composition, substrates, and hormones to the variability in energy expenditure and substrate utilization in premenopausal women. Journal of Clinical Endocrinology and Metabolism 74, 279-286.

Astrup, A., Buemann, B., Christensen, N. J. \& Toubro, S. (1994a). Failure to increase lipid oxidation in response to increasing dietary fat content in formerly obese women. American Journal of Physiology 266, E592-E599.

Astrup, A., Buemann, B., Western, P., Toubro, S., Raben, A. \& Christensen, N. J. (1994b). Obesity as an adaptation to a high-fat diet: evidence from a cross-sectional study. American Journal of Clinical Nutrition 59, 350-355.

Astrup, A. \& Flatt, J, P. (1996). Metabolic determinants of body weight regulation. In Regulation of Body Weight: Biological and Behavioural Mechanisms, Life Sciences Research report 57, pp. 193-210 [C. Bouchard and G. Bray, editors]. Chichester: John Wiley \& Sons.

Astrup, A. \& Raben, A. (1992). Obesity: an inherited metabolic deficiency in the control of macronutrient balance? European Journal of Clinical Nutrition 46, 611-620.

Astrup, A. \& Raben, A. (1995). Carbohydrate and obesity. International Journal of Obesity 19, Suppl. 5, S27-S37.

Blundell, J. E., Burley, V. J., Cotton, J. R. \& Lawton, C. L. (1993). Dietary fat and the control of energy intake: evaluating the effects of fat on meal size and postmeal satiety. American Journal of Clinical Nutrition 57, 772S-778S.

Bonadonna, R. C., Groop, L. C., Zych, K., Shank, M. \& DeFronzo, R. E. (1990). Dose-dependent effect of insulin on plasma free fatty acid turnover and oxidations in humans. American Journal of Physiology 22, E736-E750.

Boozer, C. N., Schoenbach, G. \& Atkinson, R. L. (1995). Dietary fat and adiposity: a dose-response relationship in adult male rats fed isocalorically. American Journal of Physiology 268, E546-E550.

Buemann, B., Toubro, S., Raben, A. \& Astrup, A. (1994). Substrate oxidations in postobese women on 72-h high fat diet. A possible abnormal postprandial response? International Journal of Obesity 18, 97.

De Graaf, C., Hulshof, T., Weststrate, J. A. \& Jas, P. (1992). Short-term effects of different amounts of protein, fat and carbohydrates on satiety. American Journal of Clinical Nutrition 55, 33-38. 
Dreon, D. M., Frey-Hewitt, B., Ellsworth, N., Williams, P. T., Terry, R. B. \& Wood, P. D. (1988), Dietary fat: carbohydrate ratio and obesity in middle-aged men. American Journal of Clinical Nutrition 47, 995-1000.

Hagenfeldt, L. \& Wahren, J. (1971). Metabolism of free fatty acids and ketone bodies in skeletal muscle. In Muscle Metabolism During Exercise, pp. 153-163 [B. Pernow and B. Saltin, editors]. New York: Plenum Press.

Havel, R. J., Pernow, B. \& Jones, N. L. (1967). Uptake and release of free fatty acids and other metabolites in the legs of exercising men. Journal of Applied Physiology 23, 90-99.

Heitmann, B. L., Lissner, L. \& Sørensen, T. I. A. (1995). Dietary fat intake and weight gain in women genetically predisposed for obesity. American Journal of Clinical Nutrition 61, 1213-1217.

Hill, J. O., Peters, J. C., Reed, G. W., Schlundt, D. G., Sharp, T. \& Greene, H. L. (1991). Nutrient balance in humans: effects of diet composition. American Journal of Clinical Nutrition 54, 10-17.

Hill, J. O. \& Prentice, A. M. (1995). Sugar and body weight regulation. American Journal of Clinical Nutrition 62, 264S-274S.

Hulshof, T., De Graaf, C. \& Weststrate, J. A. (1993). The effects of preloads varying in physical state and fat content on satiety and energy intake. Appetite 21, 273-286.

King, N. A. \& Blundell, J. E. (1995). Individual differences in substrate oxidation and macronutrient selection: correlation between RQ and FQ. International Journal of Obesity 19 Suppl. 2, 33.

Lissner, L. \& Heitmann, B. L. (1995). Dietary fat and obesity: evidence from epidemiology. European Journal of Clinical Nutrition 49, 79-90.

Lyon, X.-H., di Vietta, V., Milon, H., Jéquier, E. \& Schutz, Y. (1995). Compliance to dietary advice directed towards increasing the carbohydrate to fat ratio of the everyday diet. International Journal of Obesity 19, 260-269.

Mayer, J. (1955). Regulation of energy intake and body weight. Annals of the New York Academy of Sciences 63, $15-42$.

Raben, A., Andersen, H. B., Christensen, N. J., Madsen, J., Holst, J. J. \& Astrup, A. (1994). Evidence for an abnormal postprandial response to a high-fat meal in women predisposed to obesity. American Journal of Physiology 267, E549-E559.

Raben, A. \& Astrup, A. (1996). Manipulating carbohydrate content and sources in obesity prone subjects: effects on energy expenditure and macronutrient balance. International Journal of Obesity 20, Suppl. 1 (In the Press).

Raben, A., Holst, J. J., Christensen, N. J. \& Astrup, A. (1996). Correlation between subjective appetite sensation, energy intake and postprandial glucose metabolism. International Journal of Obesity 19 (In the Press).

Ritter, S. \& Taylor, J. S. (1990). Vagal sensory neurons are required for lipoprivic but not glucoprivic feeding in rats. American Journal of Physiology 258, R1395-R1401.

Rolls, B. J., Kim-Harris, S., Fischman, M. W., Foltin, R. W., Moran, T. H. \& Stoner, S. A. (1994). Satiety after preloads with different amounts of fat and carbohydrate: implications for obesity. American Journal of Clinical Nutrition 60, 476-487.

Scalfani, A. (1980). Dietary obesity. In Obesity, pp. 166-181 [A. J. Stunkard, editor]. Philadelphia, PA: Saunders.

Seidell, J., Muller, D. C., Sorkin, J. D. \& Andres, R. (1992). Fasting respiratory exchange ratio and resting metabolic rate as predictors of weight gain: the Baltimore Longitudinal Study on Aging. International Journal of Obesity 16, 667-674.

Shetty, P. S., Prentice, A. M., Goldberg, G. R., Murgatroyd, P. R., McKenna, A. P. M., Stubbs, R. J. \& Volschenk, P. A. (1994). Alterations in fuel selection and voluntary food intake in response to isoenergetic manipulation of glycogen stores in humans. American Journal of Clinical Nutrition 60, 534-543.

Stubbs, R. J. \& Prentice, A. M. (1993). The effect of covertly manipulating the dietary fat:carbohydrate ratio of isoenergetically-dense diets on ad lib. food intake in free-living humans. Proceedings of the Nutrition Society 52, 351A.

Stubbs, R. J., Ritz, P., Coward, W. A. \& Prentice, A. M. (1993). The effect of covert manipulation of dietary fat and energy density on ad lib. food intake in free-living humans. Proceedings of the Nutrition Society 52, $348 \mathrm{~A}$.

Thomas, C. D., Peters, J. C., Reed, G. W., Abumrad, N. N., Sun, M. \& Hill, J. O. (1992). Nutrient balance and energy expenditure during ad libitum feeding of high-fat and high-carbohydrate diets in humans. American Journal of Clinical Nutrition 55, 934-942. 
Tordoff, M. G., Tluczeck, J. P. \& Friedman, M. I. (1989). Effect of hepatic portal glucose concentration on food intake and metabolism. American Journal of Physiology 257, R1474-R1480.

Toubro, S. \& Astrup, A. (1995). Two years weight maintenance follow-up after major weight loss: low-fat, high-carbohydrate ad libitum diet versus calorie counting. International Journal of Obesity 19, 38.

Tremblay, A., Simoneau, J.-A. \& Bouchard, C. (1994). Impact of exercise on body fatness and skeletal muscle metabolism. Metabolism 43, 152-156.

Verboeket-van de Venne, W. P. H. G., Westerterp, K. R. \& ten Hoor, F. (1994). Substrate utilization in man: effects of dietary fat and carbohydrate. Metabolism 43, 152-156.

Wahren, J., Felig, P., Ahlborg, G. \& Jorfeldt, L. (1971). Glucose metabolism during leg exercise in man. Journal of Clinical Investigation 50, 2715-2725.

Zurlo, F., Lillioja, S., Esposito-del Puente, A., Nyomba, B. L., Raz, I., Saad, M. F., Swinburn, B. A., Knowler, W. C., Bogardus, C. \& Ravussin, E. (1990). Low ratio of fat to carbohydrate oxidation as predictor of weight gain: study of 24-h RQ. American Journal of Physiology 259, E650-E657. 